\title{
Strategije nepomirljivosti: cvijićevsko- tomašićevski kompleks u suvremenoj hrvatskoj medijskoj zbilji
}

\author{
KATARINA LUKETIĆ \\ Zagreb
}

U tekstu se analiziraju frekventne naracije o mentalitetima i identitetima na Balkanu koje se perpetuiraju u dužem periodu u ovdašnjoj javnoj sferi i zadobile su status općih istina o "Nama" i "Njima”. U fokusu je polemika na temu mentalitetskih/identitetskih nepomirljivosti između Sjeverne/Zapadne i Južne/Istočne Hrvatske koja se vodila u visokotiražnim, mainstream medijima 2009., a čiji se začetci i tragovi mogu pratiti u ranijim odnosno kasnijim tekstovima tih i drugih autora. Polemiku je izazvala serija tekstova utjecajnog novinara u kojim se ovdašnji prostor mapirao tako da su se Sjevernoj/Zapadnoj Hrvatskoj pripisala pozitivna određenja poput napredno, uljudno, obrazovano, radišno, dok su se Južnoj/Istočnoj Hrvatskoj pripisala negativna poput nazadno, divljačko, primitivno, lijeno, što je dalje uključilo distinkciju između Europe i Balkana, civilizacije i barbarstva. Takve paraznanstvene teorije - $u$ ovom slučaju obrađene prema načelima medijske spektakularizacije - zapravo su pabirci, pojednostavljene verzije teorija o balkanskim mentalitetima/identitetima Jovana Cvijića i Dinka Tomašića. Konceptualizacijom trajnih nepomirljivosti i dramatiziranjem identitetskih razlika zapravo se podržavaju naracije o sudbinskoj balkanskoj inferiornosti, vječnom hodu unatrag i osuđenosti na predmodernitet. Mentalno mapiranje tobože dubinskih mentalitetskih struktura ne uvažava niti povijesno vrijeme niti temeljnu identitetsku hibridnost koja je nastala tijekom duge povijesti migracija, međuutjecaja i miješanja na balkanskom prostoru.

Ključne riječi: mentaliteti, binarizam, esencijalizam, medijska slika svijeta, mentalne mape, Sjeverna/Zapadna i Južna/Istočna Hrvatska

\section{“ČAVOGLAVCI I NORMALNI HRVATI-PUNOGLAVCI”}

Koncert irske rock grupe U2 održan u Zagrebu u kolovozu 2009. poslužio je novinaru i publicistu Denisu Kuljišu kao povod za medijsko reaktiviranje naracija o urbanom i ruralnom, kulturnom i primitivnom, europskom i balkanskom, te za lansiranje naizgled originalne teorije o Sjevernoj/Zapadnoj i Južnoj/Istočnoj Hrvatskoj. Banalna činjenica da, unatoč tome što se popilo hektolitre piva, na zagrebačkom koncertu nije bilo nereda, tučnjavi i nacio- 
nalističkih divljanja za Kuljiša je pokazatelj sveopće zagrebačke uljudnosti i naprednosti, štoviše pokazatelj sjevernohrvatske/zapadnohrvatske trajne orijentiranosti europskim civilizacijskim vrijednostima. Uzornoj U2-publici Kuljiš je u tekstu znakovito spektakularnog naslova "U2-u bi bilo neugodno u Republici Čavoglave” objavljenog u tiražnim, mainstream dnevnim novinama Jutarnji list ${ }^{1}$ suprotstavio publiku s koncerta Marka Perkovića Thompsona održana nedugo prije toga u Biogradu na kojem je bilo više zaštitara nego publike, što nije spriječilo razbijanja, tučnjave i ispade "desnila": ustaške uniforme, nacističke pozdrave i sl. Tako je publika U2-a i publika Thompsona svaka za sebe postala u toj tabloidnoj sociologiji ne samo specifična društvena grupa sa svojim kulturnim preferencijama, životnim stilom, identifikacijama i sl., nego adekvatan uzorak koji vjerno reprezentira nacionalnu makrostrukturu, tj. određeni mentalitetsko-identitetski sklop specifičan za određeno geografsko područje. Fanovi i posjetitelji dvaju koncerata prerasli su tako u dvije osnovne i međusobno suprotstavljene nacionalne grupacije, $\mathrm{u}$ dva ključna protagonista u velikoj nacionalnoj drami. Prema Kuljišu:

U Hrvatskoj kao da supostoje dva ljudska soja - čavoglavci i normalni Hrvatipunoglavci, samo što ih je teško razlikovati po vanjštini, po imovnom stanju i mjestu obitavanja... Razlikuje ih zapravo stanje duha, pa u Zagrebu, na samo nekoliko četvornih kilometara, imaš i jednu i drugu populaciju masovno zastupljene. (Kuljiš 2009a)

Iako, dakle, i jedan i drugi nalazi u Zagrebu, “dva ljudska soja” Kuljiš u nastavku teksta predstavlja kao dva homogena i jedinstvena mentaliteta/identiteta/kulture, pa ih prestrojava i svakoga grupira na određenom prostoru. Te su grupe međusobno u stalnom konfliktu, pa između njih i u geografskom i u kulturnom i uopće svakom drugom smislu postoji civilizacijski sraz, čime autor konstruira suvremenu inačicu starog mita o predziđu, civilizacijskome sukobu i postojanju tvrdih limesa na ovome prostoru. On piše:

Kad se napravi precizna sociološka analiza, ustanoviš da su ta dva dijela hrvatskog narodnog korpusa ipak separirana, odnosno polarizirana, te da jedan naseljava Zapadnu, a drugi Istočnu Hrvatsku. Zemlja je sastavljena od dviju posve različitih država, povezanih jedino modernim prometnicama. Zapadna Hrvatska poprilično je napredna i europeizirana zemlja s razvijenom ekono-

\footnotetext{
${ }^{1}$ Ovdje se analiziraju tekstovi koji su imali snažan odjek u javnosti i koji reprezentiraju dominantne diskurzivne strategije u medijskoj sferi, a objavljeni su većinom u tiražnim tiskovinama. Naravno, u domaćoj medijskoj stvarnosti opstoji i drukčija praksa, pa neki mediji u bitno manjoj mjeri reprezentiraju "strategije nepomirljivosti" (poput Zareza, Novosti, nekih internetskih portala ili pojedinih autora/ica). No, takvi mediji nemaju ni približno takav utjecaj na stvaranje javnog mnijenja i kolektivnih uobrazilja i većinom je riječ o nezavisnim medijima (ili pak "medijima trećeg sektora"). Uz to, neki od njih nisu ni postojali u vrijeme o kojem govori ovaj tekst ili pak tada nisu iskazivali senzibiliziranost za ovakve teme.
} 
mijom, niskom stopom nezaposlenosti i strahovito skupim nekretninama. Tu se dosta dobro živi - puno se polaže i daje za kulturu, otvaraju se vrhunski restorani, buja zabava, noćni život, a japiji koji rade u komunikacijskom ili financijskom sektoru te se bave privatnim poduzetništvom, stvaraju bogatstva osnivajući kompanije koje se dinamično razvijaju. [...] A Istočna Hrvatska izrazito je zaostala, primitivna i ekonomski nerazvijena; tu vladaju siromaštvo i kriminal, pa je teritorij depopuliran, a život nesiguran. I dalje nekažnjeno haraju bande sastavljene od ratnih zločinaca, koje kontroliraju tržište droge, nameću reket i upravljaju lokalnom politikom. [...] Istočna Hrvatska živi od subvencija Zapadne Hrvatske koje prima posredstvom Vlade. (Kuljiš 2009a)

Dvije Hrvatske podijeljene su i administrativno i politički, pa je Istočna Hrvatska sastavljena "od deset županija i nekoliko bosanskohercegovačkih kantona što čini pet izbornih jedinica", 2 ona stvara "deset posto nominalnog nacionalnog dohotka", dok Zapadna čini "deset županija i metropolu" ili "šest izbornih jedinica", što "sa širom zonom predstavlja osamdeset posto nacionalne ekonomije”. Istočna Hrvatska je desničarska, glasa za HDZ, u njoj vlada "duhovna i ekonomska bijeda", ljudi su podložni utjecajima, osobito onima Crkve, zatvoreni su i zatucani. Kuljiš ih etiketira kao "white trash" i čudi se da oni "imaju isto glasačko pravo kao i obrazovani ljudi" s obzirom na to da ga oni "koriste tako da masovno glasaju za one koji se obraćaju njihovim najnižim instinktima". Zapadna Hrvatska glasa za ljevicu (SDP), tu se poštuju zakoni i različitost, tu ljudi rade i napreduju stvarajući stalno dodanu vrijednost. Stoga, Kuljiš upozorava na kraju teksta:

Na ozemlju Istočne Hrvatske mogla bi se uspostaviti desničarsko-fašistička diktatura, Republika Čavoglave, pa bi na najljepšoj lokaciji u Europi nastala jedinstvena turistička atrakcija: nacionalno etno-selo, safari-park s dvonožnim divljim životinjama koje slobodno love posjetioce - homoseksualce, bezbožnike, te strance, pripadnike nepoćudnih nacija. (Kuljiš 2009a)

\section{MENTALNE MAPE I CIVILIZACIJSKI SRAZOVI}

Nakon takve pripreme medijskog terena, uslijedilo je utvrđivanje i širenje gradiva, daljnja konceptualizacija mentaliteta/identiteta/kultura, iscrtavanje mentalne mape i definiranje poželjnih i nepoželjnih, civiliziranih i barbarskih prostora i stanovnika i njihovih osobitosti. Drugi Kuljišev tekst pod naslovom "Istočna i Zapadna Hrvatska” također objavljen u Jutarnjem listu

\footnotetext{
${ }^{2}$ Bosna i Hercegovina je ovdje iskorištena kao snažnije obilježena Drugost u odnosu na Hrvatsku, kao "pojačivač" negativnih konotacija koje nosi istočni/južni Drugi. Nadalje, njezino uključivanje ukazuje na širenje naracije na balkanski prostor, ali i na autorovo pristajanje uz nacionalistički koncept, učvršćen devedesetih, prema kojem je hrvatsko stanovništvo BiH neodvojivi dio hrvatskoga državnog korpusa.
} 
bio je opremljen i prezentiran tako da sugerira tobožnju analitičku ozbiljnost i dugotrajno istraživanje: raširen na novinskoj duplerici, s velikom kartom u boji koja je vizualizirala jasnu podjelu zemlje i sam podnaslov "Hrvatsko Kosovo: Linija Virovitica-Karlobag dijeli Hrvatsku na Istočnu i Zapadnu”, s brojčanim podacima i postocima iz popisa stanovništva, grafikonima i sl., a autor je naglasio da su njegove teze rezultat analize izbornih rezultata iz 2007. godine. Na matrici postavljenoj prvim tekstom razlike između dvije Hrvatske tu su dalje produbljene i konstruirane tako što je autor najprije iz skupine određenih kulturoloških osobitosti selektirao one koje mogu posvjedočiti o navodno dubinskoj distinkciji mentaliteta i identiteta, pa je potom svako selektirano obilježje, bilo "naše" bilo "njihovo", simplificirao i fiksirao u općim, atemporalnim kategorijama. Time su se neke realno postojeće različitosti između kulturoloških paradigmi na sjevernom i južnom ili pak zapadnom i istočnom dijelu zemlje, regionalne mnoštvenosti i mikroidentitetske specifičnosti okljaštrile, prenapuhale i predstavile kao dramatične i nepomirljive suprotnosti. Pri tome je "naše" - iz autorove perspektive sjevernohrvatsko/ zapadnohrvatsko, zagrebačko, europsko - idealizirano i uzdignuto, dok je "njihovo" demonizirano i sniženo.

Zamišljena linija razgraničenja koja dijeli uljudno od divljačkoga, civilizirano od barbarskoga, ili kako navodi, današnji "europski Zapad od balkanskog Istoka” ide glasovitom linijom Virovitica-Karlobag. Kuljiš naglašava da je riječ o liniji koju je kao "sjeverni štokavski limes" povlačio devedesetih vođa srpskih radikala Vojislav Šešelj smatrajući da ona mora određivati granice srpske i hrvatske države nakon raspada Jugoslavije. On ne spominje da zapravo nije riječ o izvornom Šešeljevu stavu kako skrojiti teritorij nakon raspada zajedničke države, nego o konceptu dužeg trajanja koji izvorište ima u velikosrpskim idejama iz 19. i s početka 20. stoljeća, među ostalima i u teorijama o geografskim i etnopsihološkim podjelama Balkana srpskoga geografa Jovana Cvijića. Kako bi se ipak uklopio u hrvatski kulturni mainstream i tip, navodno, detuđmanizirane građanske kulture kakvu su nastojale reprezentirati njegove matične novine, Kuljiš se ogradio od Šešelja i za nove teritorijalne podjele i europsko-balkanski sraz optužio Franju Tuđmana i njegove političke odluke o teritorijalizaciji Hrvatske. Potom je u raspravu uveo i stereotipnu predodžbu o lijenom i prevarantskom mediteranskom jugu usporedivši tu hrvatsku podjelu s onom između talijanskoga Sjevera i Juga. Tu analogiju nije razradio niti je spomenuo dugu i kompleksnu raspravu o tom pitanju u talijanskoj povijesti, već je efektno - kako i odgovara "palanačkoj” kulturi koja njeguje stil kao vrhunsko načelo, a ne analitičnost i preciznost $^{3}$ (Konstantinović 1991) - zaključio:

${ }^{3}$ Filozofija palanke u interpretaciji Radomira Konstantinovića, kao originalna konceptualizacija specifičnosti unutar balkanskih društava, ne uključuje kao suprotnost idealnu, građansku kulturu, niti teži totalnom uvidu u balkanska društva. Kao jedno od mnogih obilježja palanke Konstantinović izdvaja 
Istočna Hrvatska trenutačno živi od subvencija Zapadne Hrvatske koje prima posredstvom Vlade. To podsjeća na odnos talijanskog Sjevera i Juga što je doveo do secesije sjevernjačke Padanije, odakle su, siti mafije i korupcije sicilijanskog Mezzogiorna, naposljetku poručili njihovim zaštitnicima u glavnome gradu: “Ladri di Roma, e finito!" Dakle: Bando lopovska rimska, gotovo je! (Kuljiš 2009b)

Tekst završava iznova stilski bombastično, u binarnostima i dramatičnom tonu, plašeći hrvatski građanski mainstream istom retorikom kojom ga je plašio i Franjo Tuđman devedesetih - opasnošću od povratka na Balkan. Kuljiš zaključuje:

Svaki od sedam relativno velikih hrvatskih gradova treba vlastitu televiziju, dnevne novine, sveučilište, kazalište, klinički bolnički centar, muzej moderne umjetnosti i veliki nogometni klub, dok Hercegovinu i Mostar (gdje su novcem iz hrvatskog državnog proračuna sagrađeni sveučilište i bolnica) ipak treba ostaviti u inozemstvu. Možda su te ideje neostvarive fantazije, ali ako ne dođe do dubinske promjene, jaz će se povećavati, pa će doći do teritorijalne konfederalizacije. Zemlja će se stvarno, ako ne i formalno, pocijepati na jednu europsku i jednu balkansku državu. (Kuljiš 2009b) ${ }^{4}$

Složena od tuđih teorijskih pabiraka koji su dobili status tobožnjih općih istina o identitetima i mentalitetima te efektnih retoričkih ukrasa, Kuljiševa teorija o Zapadnoj/Sjevernoj i Istočnoj/Južnoj Hrvatskoj odgovarala je sasvim zakonitostima medijske spektakularizacije prema kojima se stvarnost u medijima reprezentira u krajnostima i nategnutim naracijama. Medijska slika svijeta postaje tako zasebna i samodopadna simulacija toga svijeta, a značenja se stvaraju neovisno o tome dolaze li ili ne dolaze poticaji iz stvarnosti.

Široka medijska polemika koja je uslijedila nakon tih inicijalnih Kuljiševih tekstova i u kojoj je sudjelovalo više autora nije bila usmjerena na stvarno dekonstruiranje kuljiševskog tipa mapiranja prostora, niti dekonstruiranje esencijalizma u razumijevanju dinamike društvenoga polja. Ona nije niti iskorištena za omekšavanje rigidnih identitetskih naracija uspostavljenih $\mathrm{u}$ devedesetima koje su dovele do vladavine politika neprijateljstva te do rata i stradanja (Luketić 2009), jednako kao što se u nju nisu uključile suvremene interpretacije fluidnosti i promjenjivosti identiteta u doba "tekuće modernosti" (Bauman 2011). Ukratko, ahistorijski pristup i negiranje specifičnosti

brigu za stil, a taj fokus na jezičnim i diskurzivnim obilježjima dio je i autorova interesa za odnose jezika i pojavnosti u djelima srpskih pjesnika i pisaca (vidi Biće i jezik u iskustvu pesnika srpske kulture dvadesetog veka).

${ }^{4}$ Sintagma "Hercegovinu i Mostar ipak treba ostaviti u inozemstvu" čini pokušaj da se ublaži ranije neoprezno "prisvajanje", čitanje dijela Bosne i Hercegovine kao hrvatskog prostora te jasnije distancira od Tuđmanove politike. 
nekog povijesnog "ovdje i sada", binarizam i podržavanje strogo odijeljenih i međusobno neprijateljskih mentaliteta, stereotipne predodžbe o "Nama" i "Njima", esencijalizam i reaktivacija starih mentalitetskih teorija Balkana - sve to nalazimo i u tekstovima Kuljiševih kritičara, kao i u nekim kasnijim primjerima definiranja unutarhrvatskih razlika u medijima.

Prvi je na Kuljišev utemeljiteljski tekst o Istočnoj i Zapadnoj Hrvatskoj $\mathrm{u}$ istim novinama reagirao splitski novinar i pisac Jurica Pavičić (tekst pod naslovom "Hrvatski 'zapad' živi od gluhih vučjaka"), pri čemu on nije razgradio samu binarnu strukturu niti afirmirao kompleksniju sliku prostora i identiteta, nego je promijenio vrijednosne predznake, klizeći po istom interpretacijskom pravcu napetom između dviju krajnosti. Njegova kritika također potvrđuje atemporalnu, mitsku diobu hrvatskoga prostora i identitetsku/mentalitetsku dihotomiju i esencijalizam te pristaje na objavu neke vrste trajnog identitetskog "izvanrednog stanja" na granici Europe i Balkana. Prema Pavičiću:

Doista postoje dvije Hrvatske: istočna i zapadna. Ali - ta poddioba doista jest povijesna, ona doista jest kulturna i doista jest dugog trajanja. To je poddioba na onaj dio zemlje koji je kontinuirano mogao razvijati mirnodopsku civilizaciju te onaj koji to nije mogao, a nije mogao upravo zato da ovaj drugi može. I to je stvarna priča o hrvatskom limesu: o zemlji u kojoj se u nekoj Krajini uvijek vode neki ratovi da se ne bi vodili u Zagrebu i Rijeci, o krajevima koji uvijek nanovo trpe demografske udare i prazne se da bi se stanovništvom zapunio Split, Zagreb i Pittsburgh, o gluhoj granici, krležijanskom Vučjaku u kojem će vinograd koji je posađen nesumnjivo dočekati da bude spaljen, $\mathrm{u}$ kojem se ne isplati posaditi stablo jer će ga konjica posjeći [...]. (Pavičić 2009)

U nastavku Pavičić zbog retoričkoga dojma nakratko odustaje od kulturne diobe zemlje ("Zato mi je smiješno što me Kuljiš proziva kao nacionalista: ja, naime, o Hrvatskoj imam mnogo gore mišljenje nego on i, u osnovi, uopće ne vjerujem da postoji druga Hrvatska osim te [za njega] grozomorne, 'istočne'”), da bi se potom vratio dualizmu pišući:

Ono što me duboko uzrujava u mentalitetu Kuljiša i svih njegovih istomišljenika nije samo kulturni rasizam i lakomisleno projiciranje vlastita stida na "Vlaje", "Brđane" $\mathrm{i}$ "bijesne lisice". Mnogo me više uzrujava ekonomski cinizam koji iza te retorike stoji. Naime, čitavog svijeta i čitave klase kojoj Kuljiš pripada ne bi bilo da nije bilo tog divljeg limesa. Korporacijske zgrade, sushi barovi, concept-storeovi, after-work barovi i cijela ta nadgradnja mlad og neiživljenog kapitalizma postoji zahvaljujući tome što su neki drugi gradovi gorjeli da ne bi gorio Kuljišev, što su neke druge njive minirane da ne bi njegovo dvorište, što su se neke brdske ruritanije praznile i selile u Zagreb gdje sad ti "dotepenci" voze tramvaje, lože plinaru i glasaju za Bandića. (Pavičić 2009). 
Kuljiševska Ruritanija, "Nedođija”, "mračna zemlja silovatelja i Thompsonovih slušatelja, rabijatnih divljaka koji tuku turiste i ubiru agrarne poticaje" počinje tako iza Remetinca i Dugog Sela, a "u međuvremenu hrvatska vladajuća klasa je učvrstila svoj korporacijski burg i sad joj najednom divlji graničari ne trebaju. [...] Sad, kad je novi poredak učvršćen, najednom ih strašno nerviraju ti pasivni krajevi koji bi izvolijevali potraživati od budžeta" (Pavičić 2009).

Temeljna određenja na kojima Pavičić gradi svoju verziju binarne identitetske/mentalitetske teorije o suvremenom hrvatskom konfliktu tiču se tako domoljublja i doprinosa obrani zemlje. Nova je stereotipna mentalna mapa izrađena prema sličnoj logici i jednakim retoričkim i interpretacijskim alatima: selekcijom, simplifikacijom, distinkcijama i dramatizacijom razlika između "Nas" i "Njih". Na toj je mapi Južna/Istočna Hrvatska homogeni prostor koji je objedinjen svojom povijesnom misijom obrane ostatka zemlje, dakle ratovanjem i borbom za slobodu, osobito u devedesetima, dok je Sjeverna/Zapadna Hrvatska jedinstvena po tome što je profitirala od tuđe borbe, tj. bogatila se, provodila i razvijala ekonomiju u pozadini fronta. $\mathrm{Na}$ djelu je zapravo iznova varijacija mita o predziđu u kojoj nije više cijela Hrvatska bedem koji štiti Europu od nevjerničkog Istoka, nego sada jedan njezin dio (duž granice sa Srbijom i Bosnom što se poklapa i s povijesnim "divljim limesom" i Huntingtonovom crtom sukoba civilizacije) štiti drugi omogućavajući mu time razvoj ekonomije, kulture, demokratskih institucija i sl. Dio toga mita je i naracija o nezahvalnoj i pokvarenoj Europi koja ne prepoznaje i ne cijeni dovoljno hrvatske zasluge u njezinoj obrani (obrnuta verzija mita o Europi kao civilizaciji i svjetlu; više u Čolović 2008; Luketić 2013), a ona u ovoj verziji postaje naracija o pokvarenom i nezahvalnom sjeverno/zapadnom hrvatskom stanovništvu koje ne cijeni dovoljno zasluge svojih južnih/istočnih hrvatskih branitelja.

I Kuljiš i Pavičić tako podržavaju binarizam, hijerarhiju kultura i naraciju o žrtvovanju jednih za dobrobit drugih - u Kuljiševoj verziji žrtve su radišni i civilizirani Sjevernjaci/Zapadnjaci koje iskorištavaju njihovi siromašni, lijeni, primitivni južnjački "rođaci", a na tragu jedne od najrasprostranjenijih naracija iz socijalističke Jugoslavije, aktualne osobito u zadnjim godinama postojanja zajedničke države, u kojoj su južne/istočne nerazvijene republike iskorištavale one sjeverne/zapadne. U Pavičićevoj verziji žrtve su, pak, stanovnici Juga/Istoka, koji su najprije obranili domovinu, a zatim u miru moraju "plodove svoga rada" - zaradu od turizma - davati u metropolu.

Sličan binarizam nalazimo i u jednom ranijem Pavičićevu tekstu o velikoj izložbi Dalmatinska zagora: nepoznata zemlja u Zagrebu, kojom se nastojalo afirmirati Zagoru kao kulturni specifikum i poništiti ili problematizirati negativnu stereotipizaciju toga prostora u hrvatskoj javnosti koja je inten- 
zivno na djelu 2000-ih. ${ }^{5}$ I u tom je tekstu Pavičić izgradio dva suparnička tabora, ne spominjući hibridne i složene identitetske specifičnosti koje nastaju u dodiru različitih kultura tijekom vremena na ovome prostoru. Naime, morlačka/vlaška/dinarska komponenta jedna je od identitetskih sastavnica svih obalnih gradova, ona je odraz kod Fernanda Braudela jasno opisane stoljetne dinamike između obale i zaleđa, mora i planina, pa je nije moguće u stvarnosti destilirati do njezina "čistog" oblika (Braudel 1997-98). U Pavičićevoj interpretaciji ta je komponenta, pak, predstavljena kao "čisti", homogeni i atemporalni konstrukt, ona je mitizirana i uzdignuta na razinu svehrvatskoga temeljnog kulturnog koda:

Morlački svijet je osnovni hrvatski kod, mainstream spram kojega su sve venecije i miteleurope samo manjinske kontrakulture, iznimni džepovi koji ne potvrđuju, nego tek blago razvodnjavaju pravilo. (Pavičić 2007) ${ }^{6}$

Daljnja medijska polemika fokusirala se na grad Split, koji je po Kuljišu "metropola propale Istočne Hrvatske", dok su drugi krajevi nazadnoga Istoka/ Juga ostali na margini. Demonizacija Splita kao "grada slučaja" i izrazita simplifikacija njegova kompleksnog identiteta u hrvatskim je medijima prvi put izravno iskazana 1988. u tekstu "Split vražji otok" novinara Darka Hudelista, i od tada se stereotipovi i negativne interpretacije njegova identiteta i mentaliteta perpetuiraju u različitim verzijama sve do danas. Naslanjajući se na takvu medijsku tradiciju i računajući na već ukorijenjene predodžbe o tome gradu u hrvatskoj javnoj sferi, Denis Kuljiš je polemiku o dvije Hrvatske zaokrenuo na sigurno polje. U tri broja utjecajnog tjednika Globus ${ }^{7}$ objavio je studiju slučaja Splita (tekstovi pod naslovima "Vlaji i nepoštena inteligencija", "Krici i šaputanja iz konobe" i “Popovi, lopovi i jeftine kurve”) ne analizirajući više niti izborne rezultate, niti fingirajući sociološku distanciranost. Riječ je o tekstovima nabijenim emocijama u kojima se "vražji otok" ili "grad slučaj" napada svom raspoloživom retoričkom artiljerijom, a u toj paljbi optužbi i stigmatizacija našli su se na meti različiti akteri i različite manifestacije društvenoga: provincijsko svećenstvo, predratni jugoslaveni, nacionalisti, Vlaji, malomištanska inteligencija, rimski vojnici, lokalni novinari, politički

${ }^{5}$ Izložbu je iniciralo i obilno financijski potpomoglo Ministarstvo kulture RH, a pratio ju je zanimljiv i vrijedan katalog-knjiga kao rezultat sinhroniziranoga rada mnogih kulturnih institucija.

${ }^{6}$ Takav binarizam i esencijalizam su uvriježeni načini spektakularizacije sadržaja u medijima i nije rijetkost da isti autori pišu o istim temama na drukčiji način u tekstovima koji nisu namijenjeni zabavi u medijskoj areni, pa Jurica Pavičić kompleksno i vrlo upućeno piše o stereotipizaciji na osi Balkan-Europa na filmu u svojoj znanstvenoj studiji Postjugoslavenski film: stil i ideologija. Također, autor posljednjih godina često dekonstruira uobičajene stereotipne predodžbe o identitetima i afirmira pluralnost u nizu komentatorskih tekstova vezanih uz društveno-političke aktualnosti u Europi (teme europskih podjela, odnosa između Grčke i Europske komisije, identiteta Mediterana, migranata i izbjeglica i dr.).

${ }^{7}$ Kao i Jutarnji list i Globus izdaje Europapress Holding (EPH), najveće medijsko poduzeće u Hrvatskoj. 
sektaši, feralovci, oriđinali i sl. Split je od "nekoć velikog industrijskog središta" postao "leglo korupcije i gangsteraja, gdje važnu političku ulogu ima Katolička crkva", ukratko "administrativno i kulturno sjedište korumpirane Istočne Hrvatske" (Kuljiš 2009e).

Sociolog Dražen Lalić u dnevnim novinama Slobodna Dalmacija ${ }^{8}$ to je odredio kao "četvrti veliki val konstruiranja i poticanja kolektivne predodžbe o Splitu kao o nekoj politički i kulturno iščašenoj sredini koja je sasvim kontaminirana izljevima primitivizma i urbanim teškoćama" (Lalić 2009a), a njegove reakcije na Kuljiša rijedak su primjer pokušaja da se odustane od binarizma i esencijalizacije mentaliteta i afirmira koncept hibridnosti, heterogenosti i identitetskih sklopova koji zrcale određeno povijesno "ovdje i sada". Dakle, nije riječ o pristajanju uz binarnosti i mijenjanju vrijednosnih predznaka niti konceptualizaciji društva prema načelu simplifikacije i dramatizacije razlika. Lalić ne negira neke negativne pojave kolektivnoga identiteta Splita poput: "pomanjkanja osjećaja za mjeru i sklonosti krajnostima, pretjerane vezanosti uz (bolju) prošlost i okretanja leđa budućnosti, ekstremnog kampanilizma zbog kojeg se kao manje vrijedan tretira čak i London (Ča je pusta Londra...), kolektivnog ponašanja u skladu s đirom, tj. trendom, izraženog antiindividualizma i antiintelektualizma" i sl. (Lalić 2009b), ali naglašava da te pojave treba interpretirati u širem kontekstu i kao fenomene koji ukazuju na općehrvatsko stanje. ${ }^{9}$ Novinar Davor Krile u Kuljiševoj demonizaciji Južne/Istočne Hrvatske vidio je "izvorno diskriminacijski koncept", jer autor izvodi zaključak o "kulturološkoj, obrazovanoj, demokratskoj i inoj nadmoći", a "taj diskurs pametnih metropolitanskih stratega kojima fatalno smetaju neukrotivi primitivni, a siromašni urođenici, blago rečeno, nema baš puno dodirnih točaka s duhom i načelima socijaldemokracije. Fenomen bi se kolokvijalno moglo nazvati 'materijalnim fašizmom”' (Krile 2009) ${ }^{10}$

\section{SUROGATI TEORIJA O MENTALITETU}

Kuljiševa teorija o dvije Hrvatske i civilizacijskome srazu primjer je određenoga tipa konceptualizacije i zamišljanja ovdašnjih mentaliteta i identiteta u javnoj sferi koji ima svoje duže trajanje i svoja davna izvorišta. Ona nam pokazuje koliko su moćni i trajni određeni pojmovi i određena tumačenja

\footnotetext{
${ }^{8}$ Slobodnu Dalmaciju, kao najutjecajnije novine u Dalmaciji s dugom tradicijom, u to vrijeme također objavljuje EPH, a tvrtka je većinski paket dionica kupila od države 2005. godine.

${ }^{9}$ Dražen Lalić je inzistirao na poništavanju podjela na Vlaje i fetive Splićane, došljake i građane te hibridnome identitetu Splita ranije u svojoj knjizi Split kontra Splita: pogled sociologa na problem grada.

${ }^{10} \mathrm{O}$ Kuljišu su pisali još neki autori (npr. Zlatko Gall), a cijela je polemika izazvala i reakcije na internetskim forumima, pa je na adresi www.forum.hr/archive/index.php/t-486764.html dostupna rasprava pod nazivom "Kuljiš vs. Pavičić, urbano vs. antiurbano".
} 
odnosa između prostora i kultura, odnosa Europe i Balkana, i koliko je razumijevanje ovdašnjih identiteta i mentaliteta još uvijek određeno onime što se o tim temama naučavalo prije stotinu godinu. Točnije, ono što se o mentalitetima, karakterologiji ili psihologiji naroda pisalo u prvoj polovini 20 . stoljeća i što za nas zbog čestog opisivanja genetskih i rasnih obilježja ima neugodne konotacije, danas se kamuflira u modernije i frekventnije naracije o identitetima ili kulturama (o kulturi kao novoj ideologiji više u Paić 2005).

$\mathrm{S}$ jedne strane, Kuljiševa argumentacija civilizacijske podjele Hrvatske inspirirana je općim, stereotipnim naracijama o Istoku i Zapadu, odnosno Sjeveru i Jugu, koje su dio sveeuropske kulture i kojima se upravo Europa - iz perspektive europskih središta moći - pokušavala definirati kao poželjan i viševrijedan identitet. U dominantnom tipu takva identitetskog pozicioniranja Balkan je poslužio i još služi kao alteritet, kao negativni Drugi, anti-Europa, barbarski nepoželjni dio u odnosu na koji se Europa treba konstituirati i prepoznavati (Luketić 2013; Todorova 1999). Takva europska negativna imaginacija o Istoku/Jugu kod Kuljiša je transferirana na dio ovdašnjega prostora, pa je tu riječ o tzv. "gniježđenju stereotipa”, seljenju orijentalističkih predodžbi na Balkan (Bakić Hayden 2006), pa potom daljem seljenju balkanističkih predodžbi na jedan dio Balkana i dramatiziranju "malih razlika", odnosno o konstruiranju novih balkanističkih predodžbi prema modelima koje je Zapad ranije primjenjivao na Istok (Luketić 2013). Kuljiš, dakle, polazi od takvih mitskih identitetskih određenja kao od nečega normalnoga i prirodnoga po sebi i uzima diskurs eurocentrizma koji pretpostavlja kulturnu, ekonomsku, društvenu i svaku drugu premoć određenih europskih država/ nacija kao nulto stanje. Njegovo mentalno mapiranje Hrvatske uklapa se $\mathrm{u}$ šire postavke eurocentrične imaginativne geografije koja se temelji na dihotomijama, na tobože vjekovima utvrđenim razlikama koje se niti u budućnosti neće moći promijeniti, na idejama o snažnim kulturnim srazovima, granicama, misijama za obranu Europe i sl. U toj se imaginativnoj geografiji jasno dijeli europski centar od europske periferije i ne postoji način da se ta dva konfliktna prostora povežu ili prožimaju, jer su njihove pozicije zadane i nepromjenjive, unatoč svim kulturnim utjecajima, migracijama, asimilacijama, ideji europskog zajedništva temeljenoj na istoj tradiciji i nasljeđu i sl.

S druge pak strane, teorija o dvije Hrvatske koju su u spomenutoj polemici popularizirali i Denis Kuljiš i Jurica Pavičić i koja se u različitim prilikama često oživljava u medijima ${ }^{11}$ - ima svoje izvorište u etnopsihološkim i mentalitetskim teorijama o balkanskim psihičkim tipovima i paradigmatskim ponašanjima, i to najviše onoj srpskoga geografa Jovana Cvijića (1865.-1927.),

${ }^{11} \mathrm{U}$ nizu slučajeva kvazisocioloških analiza ili komentiranja aktualnih događaja u što se uključuju dihotomije između urbanog i ruralnog, građana i došljaka, hrvatskog europejstva i hrvatskog balkanstva i sl. 
a potom i hrvatskog sociologa Dinka Tomašića (1902.-1975.). Pri tome - što je osobito važno - nije riječ o dubinskom poznavanju i izravnom naslanjanju na te autore, nego o inspiriranju digest verzijama njihovih teorija koje su se formirale tijekom kasnijeg vremena, najviše u devedesetima, i zadobile status općih istina. Poput svih drugih stereotipnih predodžbi, one slobodno kolaju balkanističkim imaginarijem, pa ih je moguće prema potrebi i nahođenju u svakom trenutku reaktivirati. Te digest verzije stvarale su, prenosile i popularizirale i hrvatske i srpske političke, medijske i kulturne elite s različitim ciljevima, od toga da se njima pokušavalo nakon raspada zajedničke države utvrditi navodno povijesno pravo na proširenje teritorija (što je činio Šešelj) do toga da se pomoću njih tumačio rat i eskalacija neprijateljstva devedesetih, o čemu će biti više riječi u nastavku.

Digest verzije, surogati izvorno kompleksnih teorija (kakva su Cvijićeva opsežna i dugotrajna istraživanja Balkana) stvaraju se tijekom vremena i prenose se u tekstovima kulture, ali još i više pomoću usmene predaje i prema načelima tzv. "kafanske znanosti". ${ }^{12} \mathrm{U}$ tome prijenosu one se banaliziraju, značenjski sužavaju i svode na univerzalno primjenjive naracije koje se temelje na dualizmu i esencijama bez uvažavanja različitih konteksta i različitih povijesnih vremena. Razlozi popularnosti i trajnosti cvijićevsko-tomašićevskog tipa konstruiranja mentaliteta i identiteta na Balkanu leže upravo u njihovoj binarnoj strukturi, jasnom pozicioniranju i atemporalnosti, što im omogućuje široku primjenjivost. Tijekom devedesetih godina Cvijićeva i Tomašićeva teorija u tim skraćenim verzijama popularizirane su i u srpskoj i u hrvatskoj sredini i korištene masovno u konstruiranju nacionalnih identiteta i utvrđivanju naših različitosti. Binarna struktura u tim teorijama dobro je poslužila u izgradnji međusobnih distinkcija i zaoštravanju identitetskih razlika, a u nju su se uklapala i već spomenuta mentalna mapiranja europskoga i balkanskoga, civilizacijskoga i barbarskoga na prostoru bivše Jugoslavije.

\section{CVIJIĆEVSKO-TOMAŠIĆEVSKA OS KONFLIKTA}

U novijem hrvatskom kontekstu Jovan Cvijić je rijetko čitan i izravno citiran, ali je pojednostavljena verzija njegove teorije o etnopsihološkim tipovima na Balkanu itekako prisutna, i to preko medijskog izvještavanja o političkim idejama oficijelne srpske politike iz devedesetih, te djelovanju srpskih

${ }^{12}$ Sintagmu "kafanska znanost" posuđujem od slovenskog pisca Drage Jančara koji ju je izrekao na jednoj književnoj tribini u Zagrebu 1988. (Jančar 1988) i premda nije riječ o znanstveno ovjerenom terminu, on dobro ilustrira uzdizanje nekih teza na rang općih istina i način njihova populariziranja u javnosti. S obzirom na kontekst i vrijeme u kojima je izrečena - rasprava o nacionalizmu u sumrak Jugoslavije - ta sintagma ne uključuje balkanističke konotacije, tj. značenja koja kasnije i u drugim kontekstima može imati riječ "kafana” u odnosu na "kavana” (balkansko-srednjoeuropski imaginariji). 
kulturnih i znanstvenih elita koje su i inspirirale takve politike. Jovan Cvijić, naime, u svome ključnom dvotomnom djelu Balkansko poluostrvo i južnoslovenske zemlje (osnove antropogeografije) ${ }^{13}$ polazi od toga da na psihičke osobine stanovnika utječu ponajviše geografske osobitosti (što je društvo primitivnije to su ti utjecaji veći), pa tek onda druge povijesne, društvene, ekonomske i ine okolnosti. Ta je knjiga, kao i njegovo drugo znanstveno i političko djelovanje (bio je član delegacije na Mirovnoj konferenciji u Parizu i autor ključnih etnogeografskih karata Balkan), imala veliki utjecaj na mnoge kasnije znanstvenike, osobito u Srbiji. ${ }^{14}$ Može se reći da je Cvijić zapravo utvrdio pojam Balkana kao zajedničkoga prostora, vrijednosnu hijerarhiju njegovih kulturnih oblasti i dominaciju određenih psihičkih tipova, a te su teze kasnije proširivali i preuzimali razni autori pišući o balkanskim identitetima i mentalitetima, među njima je najpoznatiji Vladimir Dvorniković s djelom Karakterologija Jugoslavena. ${ }^{15}$

Cvijić je godinama vodio opsežna terenska istraživanja, nastojeći najprije utvrditi geografske zadanosti prostora i različite tradicije da bi iz toga dalje definirao različite psihičke tipove. Prema njemu, osnovna geografska obilježja koja utječu na "psihologiju naroda" Balkanu su: "euroazijske osobine ili osobine civilizacije" (Balkanski poluotok kao posrednik kultura Azije i Europe), "osobine spajanja i prožimanja" i "osobine izoliranja i odvajanja". Smatrao je da postoje određene zajedničke osobine "Srbo-Hrvata, Slovenaca i Bugara" koje su oni donijeli iz zajedničke pradomovine i da su se te osobine proširile cijelim Balkanom najviše uslijed čestih migracija uzrokovanih tuđinskim osvajanjima i ekonomskim razlozima. Iako Cvijić dijeli Južne Slavene na četiri temeljna tipa: dinarski, centralni, istočnobalkanski i panonski tip s mnogim podtipovima koje manje-više temeljito analizira, u kasnijim interpretacijama Cvijićeva djela kao najvažnija se izdvajaju samo dva tipa, pa se teorija prenosi u svojoj binarnoj inačici s jasnom hijerarhijom između dvaju psihičkih i kulturnih tipova stanovništva - dinarskog i panonskog. Dinarski tip je najvitalniji i superioran na Balkanu; stanovništvo toga tipa živi u zatvorenim i međusobno čvrsto povezanim zajednicama, pa je tijekom stoljeća tuđinskih osvajanja uspjelo sačuvati stare, naglašava se "autohtone

${ }^{13}$ Izvorno objavljeno na francuskom 1918., pa prevedeno na srpski i objavljeno 1922. (sv. 1) i posthumno 1931. (sv. 2).

${ }^{14}$ I u Srbiji knjiga je bila poznata više po čuvenju do devedesetih, od kada su zaredala reizdanja, o čemu svjedoči početna rečenica: “Ovo delo se teško može naći u našim biblotekama” iz predgovora Milisava V. Lutovca izdanju Cvijićeve knjige iz 1987. (dostupno na internetskim stranicama: Projekat Rastko: Biblioteka srpske kulture na internetu).

${ }^{15}$ Dvorniković se sasvim inspirirao Cvijićem, a temeljna razlika između njihove konceptualizacije ovdašnjih mentaliteta je u tome što balkansko kod Cvijića postaje jugoslavensko kod Dvornikovića. Iako hrvatski znanstvenik, Dvorniković je u ovoj sredini manje-više zaboravljen, dok je u Srbiji njegova Karakterologija Jugoslavena drugi put objavljena pred sam raspad Jugoslavije 1990. U povodu toga reizdanja Marko Grčić je u tjedniku Globus od 17. siječnja 1991. napisao vrlo pohvalan i upućen prikaz. Glavni urednik Globusa u to vrijeme bio je Denis Kuljiš. 
balkanske vrijednosti", patrijarhalni način života i snažnu vezu s ratničkom tradicijom. Dinarci imaju snažno izražen osjećaj za obitelj i zajednicu, unutar plemena u kojemu žive međusobno si pomažu i ta svijest o pripadnosti i solidarnosti ostaje vrijediti i u modernom dobu kada dinarci odlaze iz svojih zajednica. Oni također njeguju ratničku tradiciju, očuvali su patriotska osjećanja i sjećanja na svoje slavne pretke, pa "smatraju da imaju još jednu stariju lozu, onu svojih kraljeva i careva, svojih slavnih junaka iz doba Nemanjića i Kosova, velikih vitezova, hajduka i uskoka iz turskog vremena" (Cvijić 1931: 25). Zbog svega što su ti preci preživjeli za turske vladavine, javlja se osobita "dinarska tuga" ili "istorijska tuga", pa i spremnost na osvetu. Najvredniji iskaz balkanske kulture, prema Cvijiću, čine epske narodne pjesme, u njima je sačuvana slava hajduka, pa su one najvažniji način očuvanja nacionalne svijesti i dinarske kulture. U mentalitetu dinarca najviše vrijednosti su sloboda i čast, a karakterističan je visok moral i dostojanstvo. ${ }^{16}$ S obzirom na to da se taj dinarski psihički tip u svome najčišćem obliku, prema Cvijiću, sačuvao najviše u Crnoj Gori i zatim u području Dinarida, koji su nastanjeni uglavnom, tvrdi on, srpskim stanovništvom, jasno je da je ta teorija o superiornim dinarcima odlično poslužila srpskim elitama krajem osamdesetih i početkom devedesetih godina kao povijesna ovjera njihovih osvajačkih politika (hrvatsko stanovništvo veže samo uz uski kajkavski krug, dok o bošnjacima govori kao o islamiziranom srpskom stanovništvu).

Za razliku od dinarskog tipa, panonski tip, koji mahom nastanjuje područje sjeverne Hrvatske, Slovenije i Vojvodine, izgubio je svoju vitalnost i njegova je nacionalna svijest umrtvljena dugogodišnjom podložnosti stranim osvajačima. Jednako snižava i "bošnjački mentalitet" poturčenoga stanovništva, koje karakterizira mlakost, "neuravnoteženost", "duhovna skučenost" (Cvijić 1933: 80). Pripadnike panonskog tipa, pak, karakterizira "maštanje a ne stvarnost", gubitak veze s ratničkom tradicijom, zaborav izvorne balkanske prakulture, gubitak snage, licemjerje, uopće duhovna slabost. Ti su ljudi u povijesti bili zavaravani trenutačnim dobrobitima Austrije i njihova je politika značila popuštanje, konformizam i ulagivanje. Cvijićevo uzdizanje dinarske kulture kao kulture vitalizma i proglašavanje Srba nositeljima te autentične balkanske kulture ukorijenjeni su u velikoj naraciji o srpskoj nadmoći na ovome prostoru, pa i dinarcu kao jedinom pravom genius loci Balkana, kao novom Barbarogeniju koji ima premoć u odnosu na pripadnike drugih nemoćnih i dekadentnih (više europskih, a manje originalnih) kultura ovoga prostora. Kako se Cvijićeva teorija primjenjuje i nakon devedesetih na suvremenu društvenu dinamiku u Srbiji ilustrira dobro citat (svojevrsni

${ }^{16}$ I Cvijić, i Tomašić, i Dvorniković, i drugi autori teorija o balkanskoj psihologiji naroda i mentalitetima uzimaju u obzir samo manifestacije, specifičnosti i iskaze muške kulture, dok žensku kulturu: način života, svakodnevicu, položaj u obitelji i dr., spominju usputno i uvijek izdvojeno u zasebnim minipoglavljima. 
pandan Kuljiševom remakeu) iz novinskog feljtona pod nazivom Koreni naših sukoba srpskog antropologa Miloša Bogdanovića, koji inače svoje teze objedinjuje u nazivu "Karakterologija Zapadnog Balkana":

Sukob između Srba i Hrvata je zapravo sukob između dva starosedelačka rasna tipa na Balkanu, sa kojima pravi Sloveni, kao vrlo razumna populacija, nemaju gotovo nikakve veze. Kada Srbi kritikuju Hrvate, tad kritikuju karakter alpskog rasnog tipa, koji je dominantan u Hrvatskom Zagorju, ali i u starosedelačkom stanovništvu Vojvodine, posebno Banata. Kada Hrvati kritikuju Srbe, udaraju na karakter dinarskih starosedelaca, koji su dominantni u Crnoj Gori, Hercegovini i zapadnoj Srbiji, ali i u Dalmaciji. Naravno da su Hrvati dinarskog porekla istog karaktera kao i Srbi dinarskog porekla. Kao što su i Srbi alpskog tipa u Vojvodini istog karaktera kao Hrvati iz Zagorja. Dinarski i alpski tip imaju potpuno različito genetsko poreklo. Dinarce odlikuje nulta krvna grupa, a alpide izražena A grupa. Dinarci su narod proto-egipatskog porekla, genetski blizak mediterancima i mnogim afričkim i indijanskim plemenima, dok su alpidi ugrofinskog porekla, starosedioci nekada zaleđene Evrope, genetski bliski mongolima i nordidima. Iako su obe populacije sklone sukobima i autoritarnoj savesti, one imaju potpuno različite motive koji ih navode na međusobne sukobe. Njihov karakter je potpuno suprotan i zbog slabosti podložan manipulaciji. Dinarcem se lako manipuliše pobuđivanjem i zadovoljavanjem njegove sujete, a alpidom buđenjem osećanja krivice. Kao što dinarac nije u stanju da razume jednog alpida, tako i alpid nije u stanju da razume jednog dinarca, kako on može tako otvoreno i bez ikakve savesti da čini ono što ne valja, i još da se time ponosi?! (Bogdanović 2003)

Hrvatski sociolog Dinko Tomašić tridesetih godina 20. stoljeća izložio je svoju teoriju o dominantnim balkanskim psihičkim tipovima/mentalitetima u prošlosti koji su odredili i kasniju strukturu društva kao reakciju na Cvijića. No, za razliku od Cvijićeva, Tomašićevo djelo nema široki kulturološki karakter, niti je nastalo kao rezultat temeljitih terenskih istraživanja, a distinkcija između dvaju mentalitetskih tipova i generalizacije o njima su još i izražajnije. Tako u tekstu "Plemenska kultura i njezini današnji ostaci" iz 1936. godine Tomašić iznosi tezu o dvjema autohtonim kulturama na Balkanu - zadružnoj i plemenskoj kao idealtipovima prema kojima se i danas tektonski razlikuju kulture Hrvata i Srba, pri čemu samo usputno spominje druge tipove kultura, uglavnom nomadskih, smatrajući da su se one tijekom vremena asimilirale u ova dva tipa. U zadružnoj kulturi ljudi su bili organizirani u zadrugama, bavili su se uglavnom ratarstvom i manje stočarstvom, selili su se u manjim skupinama i mirno zauzimali nova područja, a kako su ovladali određenim ratarskim vještinama bili su prihvaćeni od drugih starosjedilaca. Plemenska kultura se, pak, zasnivala na stočarenju, ljudi iz te kulture bili su nomadi, zauzimali su strateški važne položaje u blizini drugih stočara ili trgovačkih putova, pa su s vremenom iz stočarsko-nomadske kulture prešli u pljačkaško-ratničku, 
nastanili se trajno na nekom teritoriju i bavili se hajdučijom, gusarenjem, pljačkom. Oni su sasvim lojalni svome plemenu, a nova područja osvojili su nasilno i ratovanjem. Često je "čitavo pleme oruđe u rukama istaknutih glavarskih porodica, služe im u njihovim pljačkaško-ratničkim podvizima i podržavaju njihove nasilničke i autokratske težnje, za koje snose i solidarnu odgovornost putem institucije krvne osvete" (Tomašić 1993a: 892). Plemenski tip karakterizira "fizička snaga, obilnost energije izgrađene uslijed obilnosti hrane i obilnosti dokonog vremena" (isto: 891), zatim nasilnost, agresivnost, impulzivnost, strastvenost, autokratske težnje, neprijateljstvo prema drugima, ali i velika privrženost zajednici. Riječ je o izrazito patrijarhalnoj kulturi u kojoj je "pljačka jedino dostojno zanimanje muškarca" (isto: 893), a zbog nesigurnosti takva života i patrijarhalnosti tu su se sačuvale i velike razlike među spolovima. Za razliku od toga, prema Tomašiću, u zadružnoj kulturi žene imaju znatno bolji položaj, s obzirom na to da je osnovna djelatnost poljoprivreda, one ostaju kod kuće, bave se vrtlarstvom, razvijaju oruđa za rad i imaju vidljiviju ulogu u društvu. On je zadružnu kulturu posebno analizirao na primjeru mikrokulture Hrvatskog zagorja gdje nema ni traga epskoj herojskoj poeziji (uglavnom je riječ o lirici), žene imaju veću ulogu u zajednici, vlada individualna miroljubivost s povremenim izljevima kolektivnog bunta u seljačkim bunama, koje nisu imale revolucionaran ili osvajački, već obrambeni karakter (Tomašić 2013). Sve negativno i destruktivno na ovome prostoru, kako tvrdi u tekstu "Struktura balkanskog društva", vezano je uz dominaciju plemenske kulture, a balkanski dinarci prenijeli su u 20. stoljeće svoje oblike organizacije zajednice, "dinastički despotizam, pretorijanstvo, vladavinu policije i potkupljivu birokraciju” (Tomašić 1993b: 941), s time da se društvo naglašeno militariziralo i podijelilo u suprotstavljene frakcije. Prema njemu, jedina mogućnost da se balkanska društva demokratiziraju jest upravo demilitarizacija i odustajanje, zbacivanje plemenskog tipa vlasti i upravljanja. Naime, iz plemenskog/dinarskog korpusa se dosada formirala svaka vlast na Balkanu, i ona u prvoj Jugoslaviji u kojoj je dominirala srpska dinarska komponenta, i ona komunistička nakon Drugog svjetskog rata.

Cvijićeva i Tomašićeva teorija tako su u osnovi slične: u obje se polazi od idealtipskih društvenih struktura i psihičkih tipova te utvrđuje postojanje trajnog konflikta između takvih struktura, tj. između mentaliteta i kultura na Balkanu. Riječ je istoj dualnosti i istoj odanosti strukturalizmu, istom podržavanju geografskog determinizma, pri čemu su zamijenjeni tek vrijednosni predznaci. Cvijićevi superiorni dinarci (ratnici, hajduci, epski pjevači, čuvari patrijarhalne autentične kulture) postaju kod Tomašića divljaci i destruktivci (pljačkaši, autokrati, agresivni vođe, nasilnici), odnosno slabi i podložni panonci kod prvoga (strani poslušnici, ljudi bez vitalnosti, licemjeri) postaju miroljubivi i napredni pripadnici zadružne kulture kod drugoga.

Zbog svoga rada, a posebno onoga njegova dijela koji se ticao hrvatske nacionalne ideje i aktivnosti u okviru lijevog krila tadašnjega HSS-a, Dinko 
Tomašić je bio kritiziran i napadan, ${ }^{17}$ a neposredno prije Drugog svjetskog rata zbog straha da je na crnoj listi ustaškog režima emigrirao je u SAD. U Americi živi do kraja života, predaje na nekoliko sveučilišta i dalje razrađuje svoje teorije o društvenoj strukturi Balkana i autokratskoj naravi svake komunističke vlasti (komunizam i društveni razvitak u Sovjetskom Savezu tumačio je pomoću temeljnog sukoba divljih tatarskih nomada i miroljubivih staroslavenskih poljodjelaca). U socijalističkoj Jugoslaviji Tomašićev je rad bio zaboravljen i marginaliziran upravo zbog njegova antikomunizma i kritike Titove vlasti, da bi početkom devedesetih godina bio rehabilitiran od strane vodećih hrvatskih znanstvenika, i to ne samo kao neosporno jedan od prvih domaćih sociologa i autora teorije o mentalitetima, nego i kao sociolog-vizionar koji je davno opisao temeljne razlike između Srba i Hrvata, ili u drugoj inačici, između dvaju tipova kulture u Hrvata, i detektirao razloge suvremenih sukoba - čak te sukobe i predvidio. Tako su u časopisu Društvena istraživanja 1993. iznova štampani Tomašićevi ključni radovi iz tridesetih godina ("Plemenska kultura i njeni današnji ostaci" i "Struktura balkanskog društva"), uz osvrte nekoliko sociologa, antropologa i psihologa (Aleksandar Štulhofer, Mladen Čaldarević, Miroslav Goreta, Vjeran Katunarić, Hrvoje Lorković, Dunja Rihtman-Auguštin, Ivan Rogić, Josip Županov) koji su na različite načine i neki s jačim kritičkim odmakom interpretirali Tomašića (poput Županova koji je upozoravao da je Tomašić isključio mediteransku-građansku kulturu iz svoje teorije). No, punu rehabilitaciju i popularizaciju u hrvatskoj javnoj sferi devedesetih Tomašićeva je teorija dobila zahvaljujući djelovanju dvojice sociologa, najviše Slavena Letice, te nešto manje Stjepana Meštrovića. ${ }^{18}$ Letica je kao publicist i tzv. "intelektualac opće prakse" u više medijskih istupa zastupao naracije o sukobu plemenske/dinarske i panonske/zadružne kulture kao paradigmatskom sukobu na Balkanu koji je bio i razlogom srpsko-hrvatskog rata. Stjepan Meštrović je, pak, samostalno ili u suradnji s Leticom i Miroslavom Goretom objavio nekoliko radova na engleskom jeziku u kojima je također pomoću Tomašićeve dihotomije tumačio ratne događaje. ${ }^{19}$ Ukratko, prema njihovim interpretacijama, plemenski mentalitet kao nositelj svega negativnoga, nazadnoga i nasilnoga opstoji i u devedesetima, štoviše on tada dominira političkim životom, iz njega se regrutiraju akteri

${ }^{17}$ Tomašić je napadnut i fizički, i to usred javnog predavanja 1937. u zgradi Pučkog učilišta od strane studenata frankovaca. Više o tome u tekstu Aleksandra Štulhofera: "Prijetnje, zaborav i tragovi: o recepciji Tomašićeva djela".

${ }^{18}$ Upravo je Globus u vrijeme kada je glavni urednik bio Denis Kuljiš uveo Stjepana Meštrovića u hrvatski javni prostor objavivši nekoliko intervjua s njime 1992. autori kojih su bili Marko Grčić i Denis Kuljiš. Također, u istom je tjedniku u to vrijeme redovnu kolumnu imao Slaven Letica u kojoj je više puta pisao, između ostalih, i o balkanskom tipu vlasti i razlikama mentaliteta na Istoku i Zapadu.

${ }^{19}$ U tome su najvažniji tekstovi Slavena Letice “Jesu li Dinarci trajno konvertibilni”, Start, br. 555, 28. travnja 1990. i "U Hrvatskoj dominiraju ministri podrijetlom iz Hercegovine i Dalmatinske zagore”, Globus, br. 204, 4. studenoga 1994. te knjiga Stjepana Meštrovića, Slavena Letice i Miroslava Goreta Habits of the Balkan Heart iz 1993. 
vlasti, što dovodi do nasilnog raspada Jugoslavije, rata i oživljavanja osvajačkih politika. Jugoslavija se raspala zbog sukoba kolektivnih mentaliteta i pobjede plemenske/dinarske kulture i sve dok na ovome prostoru vlast ne bude formirana od pripadnika zadružne kulture neće biti demokracije. Pri tome Meštrović dinarsko veže samo uz pravoslavno stanovništvo Balkana i uz Srbe (ne radi razliku između tadašnje srpske politike i same nacije), dok katolici, Hrvati pripadaju miroljubivom i naprednom zadružnom tipu. Rat se tu tumači kao sukob plemenske i zadružne kulture, ali i sukob religija i sukob civilizacija, pa se slažu nove dihotomije između pravoslavlja i katoličanstva, urbanog i ruralnog, europskog i balkanskog itd. Taj tip analize ukorijenio se u jednom dijelu medija i dinarci su iz hrvatske perspektive u poznatoj strategiji transferiranja stereotipova postali nositelji svega negativnog, divljačkog, nazadnog, ukratko dinarci su postali jednaki pravoslavcima/ Srbima/Jugoslavenima/Balkancima i najopasnijim europskim barbarima, dok su Tomašićevi panonci postali nositelji miroljubive politike, napretka, kulture - a to su katolički Hrvati i Europljani. O tom sukobu mentaliteta/ kultura na Balkanu kao ključnom razlogu za rat i "jednoj od najzastupljenijih koncepcija kojom trenutno barata hrvatsko mnijenje", Aleksandar Štulhofer u tekstu "Predviđanje rata? - Etnosociologija Dinka Tomašića" piše:

Radi se o uvjerenosti da su konflikti, a onda i sam rat, izraz temeljne različitosti i inkompatibilnosti dvaju kulturnih krugova. Evropskog, kojem pripada hrvatski narod, te onog balkanskog, bizantsko-otomanskog, kojeg reprezentiraju Srbi. (Štulhofer 1992: 300)

Kao inspiratore te naracije o nepomirljivoj različitosti Štulhofer spominje i Antu Starčevića i Milana Šufflaya, ${ }^{20}$ koncentrirajući se nadalje u tekstu samo na Tomašića. S pravom Štulhofer naglašava da Tomašićeva koncepcija nije bila zamišljena kao nepromjenjiva, s obzirom na to da su plemenski i zadružni modeli tek idealni tipovi i da se pod utjecajem okoline mijenja njihovo "psihičko stanje". No, iako spominje povijesne promjene, činjenica je da ih Tomašić nije razradio i da su u kasnijem prijenosu i spomenutoj digest verziji njegove teorije mentaliteta ostali upamćeni samo čvrsti i zatvoreni idealni tipovi.

\section{DUGOTRAJNI TRANSFERI ISTIH NARACIJA}

Cvijićeva i Tomašićeva teorija su tako ostale upamćene u svojim simplificiranim verzijama u kojima se iskristalizirao upravo binarni, mitski sukob

${ }^{20}$ Milan Šufflay je također rehabilitiran od strane dijela nacionalističke inteligencije početkom devedesetih, kada se preštampavaju njegova djela, organiziraju simpoziji, postavljaju spomen-obilježja i sl. 0 tome više u Luketić (2013). 
dvaju različitih i suprotstavljenih etnopsiholoških tipova koji traje tijekom cijele povijesti. U obje se teorije pretpostavlja dominacija jednoga tipa nad drugim te nastoji u nepromjenjivim etno-psihološkim kategorijama tumačiti svu povijesnu dramatiku balkanskog prostora. To su postale najfrekventnije teorije o psihološkim tipovima na Balkanu i osnovice za daljnje konceptualizacije nacionalnih identiteta i nacionalnih kultura. Dualnost koja je jednom upisana u veliki tekst kulture u njemu opstoji niz godina, pa se u različitim fazama može izvlačiti i reafirmirati kao opća istina i adekvatno tumačenje stvarnosti.

$\mathrm{U}$ konstruiranju hrvatskog nacionalnog identiteta $\mathrm{u}$ ratnim godinama te binarne, simplificirane naracije imale su veliku ulogu, pomoću njih se konstruirala naracija o dugom neprijateljstvu i ključnoj, civilizacijskoj razlici između Hrvata kao reprezentanata europske civilizacije i Srba kao reprezentanata balkanskog barbarstva. Hrvatski nacionalni identitet se tada oblikovao upravo kao razlikovni identitet, pri čemu su kategorije dinarskoga i panonskoga ili plemenskoga i zadružnog onako kako su one značenjski uspostavljene kod Dinka Tomašića imale ključnu ulogu.

$\mathrm{U}$ transferiranju stereotipova $\mathrm{u}$ poslijeratnoj Hrvatskoj ta je temeljna binarnost dobila nove inačice, pa su uljudnom, europskom, hrvatskom identitetu i konačno uspostavljenoj prevazi nasljednika zadružnog tipa, miroljubivim tomašićevskim panoncima, kako piše Jurica Pavičić u spomenutom tekstu, počeli prijetiti neki novi Drugi, hrvatski agresivni i primitivni dinarci, ukratko "naši unutarnji Balkanci". I dok je tijekom devedesetih dominantno bila riječ o tome da su se Jugoslavija, tj. Srbija i druge istočne/južne novonastale države (ovisno već o političkoj potrebi) proglašavale neprijateljskim barbarskim Balkancima, nakon dvijetisućite godine ulogu neprijateljskog, zaostalog, divljačkog Drugog prebacuje se na stanovništvo Zagore, Hercegovine, na "Vlaje”, doseljenike iz "pasivnih krajeva”, ljude "kamenih gena”, domaće Ruritance i sl. (a njih i Tomašić i Cvijić navode kao reprezentativne dinarce). Dakle, isti tip cvijićevsko-tomašićevskog kompleksa u kojemu se mentaliteti/ nacije/kulture na Balkanu dijele u dvije međusobno suprotstavljene, a unutar sebe homogene kategorije perzistira na ovome prostoru dugo vremena i $\mathrm{u}$ različitim se vremenima i različitim inačicama iznova aktivira. U srpskom javnom mnijenju devedesetih prevagnula je cvijićevska interpretacija, pa je dinarska kultura bila herojska kultura, oživjela je cijela hajdučka mitologija, pozivalo se na povijesne osvete, minoriziralo kulturu susjednih naroda i sl. ${ }^{21}$ U hrvatskoj je oficijelnoj kulturi tih godina bilo dominantno viđenje cijele

${ }^{21}$ Od brojnih primjera spomenut ću samo nekoliko: kult hajdučije kod vođa bosanskih Srba u ratu, otpor prema dinarskom vitalizmu pomoću veličanja srpske nizinske kulture moravskih seljaka u hit romanu s kraja osamdesetih Knjiga o Milutinu Danka Popovića, naraciju o slaboj, imitatorskoj hrvatskoj kulturi i austrijsko-konjušarskom mentalitetu Slovenaca i Hrvata Emira Kusturice i sl. 
nacije kao miroljubivih, radišnih i naprednih izdanka zadružne kulture, dok su državi prijetila osvajačka, agresivna, ruralna, barbarska dinarska/ srpska plemena. Isti binarizam, istu dramatizaciju razlika i isto svođenje nekog složenog, dinamičnog i heterogenog identitetskog korpusa na fiksne i suprotstavljene krajnosti nalazimo i u Kuljiševoj tezi o Sjevernoj/Zapadnoj i Istočnoj/Južnoj Hrvatskoj i U2-ovoj urbanoj publici kojoj prijeti propast u Republici Čavoglave. Nalazimo ih i u Pavičićevoj tezi o dvije Hrvatske - onoj koja ratuje i onoj koja planduje; kao što ih nalazimo i u brojnim drugim slučajevima poput npr. veličanja tzv. “ognjištarske kulture” u djelima Ivana Aralice, isticanju dinarskog korpusa sa njegovom epikom i folklorom koji je sačuvao hrvatsku nacionalnu ideju tijekom povijesti i sl.

Tako postavljene, vječne i nepromjenjive binarne mentalitetske teorije na ovim prostorima su teorije retardacije u kojima se podržava vječiti hod unatrag i u kojima se negiraju mogućnosti vlastitoga razvoja i razvoja identitetski heterogenoga građanskog društva. Njihovim perpetuiranjem u utjecajnim, mainstream medijima ove kulture se osuđuje na vječni predmodernitet, na stalno igranje istih uloga zadanih prije mnogo godina, na vječnu vrtnju u ahistorijskom mitskom vremenu, bez perspektive da se zakorači u budućnost.

\section{NAVEDENA LITERATURA I IZVORI}

Atkinson, David, Peter Jackson, David Sibley i Neil Washbourne, ur. 2008. Kulturna geografija. Kritički rječnik ključnih pojmova. Zagreb: Disput.

Bakić-Hayden, Milica. 2006. Varijacije na temu "Balkan". Beograd: Institut za filozofiju i društvenu teoriju, Filip Višnjić.

Bauman, Zygmunt. 2011. Tekuća modernost. Zagreb: Pelago.

Bogdanović, Miloš. 2003. "Koreni naših sukoba”. Večernje novosti, 28. listopada 2003.

Bougarel, Xavier. 1999. "Yugoslav Wars. The 'Revenge of the Countryside' between Sociological Reality and Nationalist Myth". East European Quaterly 33/2: 157-175.

Braudel, Fernand. 1997-98. Sredozemlje i sredozemni svijet u doba Filipa II. Zagreb: Antibarbarus.

Cvijić, Jovan. 1922. Balkansko poluostrvo i južnoslovenske zemlje (osnove antropogeografije). Geografska sredina i čovek. Beograd: Državna štamparija Kraljevine Srba, Hrvata i Slovenaca.

Cvijić, Jovan. 1931. Balkansko poluostrvo i južnoslovenske zemlje (osnove antropogeografije). Psihičke osobine Južnih Slavena. Beograd: Izdavačka knjižarnica Gece Kona.

Čolović, Ivan. 2008. Politika simbola. Ogledi o političkoj antropologiji. Beograd: Radio B92.

Ćulibrk, Svetozar. 1982. Cvijićeva sociologija Balkana. Beograd: Prosveta.

"Sociologija Dinka Tomašića”. 1993. Društvena istraživanja 2/6.

Dvorniković, Vladimir. 1990. Karakterologija Jugoslavena [drugo izdanje]. Niš: Prosveta.

Gall, Zlatko. 2009. “Zona sumraka. Šugavi stereotipi ili: kudi se istok i zapad”. Slobodna Dalmacija, 19. rujna 2009. 
Goffman, Erving [Gofman, Erving]. 2000. Kako se predstavljamo u svakodnevnom životu. Beograd: Geopoetika.

Jančar, Drago. 1988. "Klaustrofiloksenofobija ili blagdanski doprinos jugoslavenskom ludilu”. Danas, 13. prosinca 1988.

Konstantinović, Radomir. 1983. Biće i jezik u iskustvu pesnika srpske kulture dvadesetog veka. Beograd: Prosveta, Rad, Matica srpska.

Konstantinović, Radomir. 1991. Filozofija palanke [drugo izdanje]. Beograd: Nolit.

Krile, Davor. 2009. "Metastaze. Buni se Istok na Zapadu: Dalmacija to nije zaslužila”. Slobodna Dalmacija, 28. kolovoza 2009.

Kuljiš, Denis. 2009a. "U2-u bi bilo neugodno u Republici Čavoglave”. Jutarnji list, 12. kolovoza 2009.

Kuljiš, Denis. 2009b. “Istočna i Zapadna Hrvatska”. Jutarnji list, 22. kolovoza 2009.

Kuljiš, Denis. 2009c. "Split: Metropola propale Istočne Hrvatske 1. Vlaji i nepoštena inteligencija". Globus, 2. rujna 2009.

Kuljiš, Denis. 2009d. "Split: Metropola propale Istočne Hrvatske 2. Krici i šaputanja iz konobe”. Globus, 9. rujna 2009.

Kuljiš, Denis. 2009e. "Split: Metropola propale Istočne Hrvatske 3. Popovi, lopovi i jeftine kurve". Globus, 23. rujna 2009.

Lalić, Dražen. 2003. Split kontra Splita. Pogled sociologa na probleme jednoga grada. Zagreb: Naklada Jesenski i Turk.

Lalić, Dražen. 2009a. "Kuljiševi majmuni, lopovi i papci najčešće imaju ZG registraciju. Dražen Lalić o novom pokušaju da se Split predstavi kao grad slučaj". Slobodna Dalmacija, 9. listopada 2009.

Lalić, Dražen. 2009b. “'Mrdušani' potiskuju 'Glembajeve' dok građani 'kibiciraju' iz svojih dnevnih boravaka". Slobodna Dalmacija, 18. listopada 2009.

Letica, Slaven. 1990. “Jesu li Dinarci trajno konvertibilni”. Start, 28. travnja 1990.

Letica, Slaven. 1994. "U Hrvatskoj dominiraju ministri podrijetlom iz Hercegovine i Dalmatinske zagore". Globus, 4. studenoga 1994.

Luketić, Katarina. 2009. "Prošlost je naša budućnost". U Zid je mrtav, živeli zidovi. Pad Berlinskog zida i raspad Jugoslavije. Ivan Čolović, ur. Beograd: Biblioteka XX vek.

Luketić, Katarina. 2013. Balkan. Od geografije do fantazije. Zagreb: Algoritam.

Meštrović, Stjepan, Slaven Letica i Miroslav Goreta. 1993. Habits of the Balkan Heart. Social Character and the Fall of Communism. Texas University Press, College Station.

Paić, Žarko. 2005. Politike identiteta. Kultura kao nova ideologija. Zagreb: Antibarbarus.

Pavičić, Jurica. 2007. "Zagora: Tko još ne voli rolling stonse?” Jutarnji list, 8. rujna 2007.

Pavičić, Jurica. 2009. “Hrvatski 'zapad' živi od gluhih vučjaka”. Jutarnji list, 29. kolovoza 2009.

Pavičić, Jurica. 2011. Postjugoslavenski film. Stil i ideologija. Zagreb: Hrvatski filmski savez.

Popović, Danko. 1986. Knjiga o Milutinu. Beograd: Književne novine.

Rogić, Josip. 1965. “Jovan Cvijić i njegovo djelo. Povodom 100-godišnjice rođenja”. Geografski glasnik 27.

Štulhofer, Aleksandar. 1992. "Predviđanje rata? - Etnopsihologija Dinka Tomašića”. Društvena istraživanja 1/2: 299-313.

Štulhofer, Aleksandar. 1993. “Prijetnje, zaborav i tragovi. O recepciji Tomašićeva djela”. Društvena istraživanja 2/6: 981-988. 
Todorova, Maria. 1999. Imaginarni Balkan. Beograd: Biblioteka XX vek.

Tomašić, Dinko. 1993a. "Plemenska kultura i njeni današnji ostaci". Društvena istraživanja 2/6: 889-906.

Tomašić, Dinko. 1993b. “Struktura balkanskog društva”. Društvena istraživanja 2/6: 939-948.

Tomašić, Dinko. 2013. Društveni i politički razvitak Hrvata. Zagreb: Naklada Jesenski i Turk, Hrvatsko sociološko društvo.

\title{
STRATEGIES OF IRRECONCILABILITY: THE CVIJIĆ-TOMAŠIĆ COMPLEX IN CONTEMPORARY CROATIAN MEDIA REALITY
}

\begin{abstract}
SUMMARY
The article presents an analysis of common narrations about mentalities and identities in the Balkans, which have been perpetuated for a long time in the public sphere, and have acquired the status of general truths about "Us" and "Them". The article focuses on the controversy regarding the mentality/identity irreconcilability between Northern/Western and Southern/Eastern Croatia that broke out in the high-circulation, mainstream media in 2009 , which can be traced back to earlier texts by the same and other authors and can be seen in their later texts. The public controversy was caused by a series of texts by an influential journalist, whereby Northern/Western Croatia was attributed positive characteristics such as progressive, polite, educated, hard-working, and Southern/Eastern Croatia was attributed negative characteristics such as backward, savage, primitive, lazy; thus incorporating the distinction between Europe and the Balkans, i.e. civilization and barbarianism. Such parascientific theories - in this case presented through the framework of media spectacularization are compilations, simplified versions of Jovan Cvijić's and Dinko Tomašić's theories about Balkan mentalities/identities. Referring to persistent irreconcilabilities and exaggerating identity differences is a way to reinforce narratives about preordained Balkan inferiority, constant backwardness, and being doomed to premodernity. The mental mapping of the supposedly ingrained mentality structures does not take into account the time in history or the basic hybridity of identity that developed during the long history of migrations, mutual influences and mixing in the Balkans.
\end{abstract}

Keywords: mentality, binarity, essentialism, media image of the world, mental maps, Northern/Western and Southern/Eastern Croatia 